\title{
Pszichoszomatikus tünetek és betegségek: a medicina vakfoltja
}

\author{
Rajna Péter dr.
}

Semmelweis Egyetem, Általános Orvostudományi Kar, Pszichiátriai és Pszichoterápiás Klinika, Budapest

Bevezetés: A pszichoszomatikus medicina területéhez tartozó betegek ellátása rossz hatásfokú. Ez egyaránt jelentős terhet jelent a betegek és az egészségügy számára.

Célkitüzés: A pszichoszomatikus tünetek és betegségek megjelenésének és ellátási ajánlásainak vizsgálata az irányadó hivatalos szakmai anyagban.

Módszer: Az adatgyújtés időpontjában elérhető 531 Szakmai irányelvből annak a 134 dokumentumnak a részletesebb elemzése, amelynek témájában pszichoszomatikus tünetek/betegségek gyakoribbak. Ebből 39 egyértelmúen pszichoszomatikus vonatkozású anyag tartalmi vizsgálata, továbbá a Szakmai Kollégiumok listáján szereplő három pszichiátriai szakterület összes (26) szakmai irányelvének hasonló szempontú értékelése.

Eredmények: A megvizsgált irányelvek töredéke tartalmaz csupán a pszichoszomatikus tünetképzésre, illetve kezelésre, megelőzésre vonatkozó megállapítást. A releváns témájú irányelvekben szereplő diagnosztikai utalások aránya: direkt 10,25 , indirekt forma 23,7 , a terápiás ajánlások között direkt 25,64, indirekt forma $15,38 \%$. A megelőzésre vonatkozóan alig $(5,12 \%$-ban) szerepel említés, a pszichés betegségek egyidejű fennállásának esélyére is mindössze 10,25\%-ban történik megállapítás. A szorongásos zavarok befolyásáról kevesebb, mint minden harmadik irányelv számol be (30,76\%). A pszichiátriai irányelvek között pszichoszomatikus betegségekre vonatkozóan nincs célzott szakmai irányelv. Következtetés: A pszichoszomatikus medicina a hatékony betegellátás követelményeit meghatározó szakmai irányelvekben elégtelen arányban jelenik meg. Okait szemléleti zavarokban, a pszichiátriai szakmai konszenzus és a szakmaközi együttmúködés hiányosságaiban kell keresni. Mind a vonatkozó kutatásokban, mind az irányelvek fejlesztése során erőfeszítéseket kell tenni a fentiek miatt kallódó nagy betegpopuláció hatékonyabb ellátása érdekében. A szerző javaslatot tesz a szükséges konkrét lépésekre.

Orv Hetil. 2021; 162(7): 252-261.

Kulcsszavak: pszichoszomatikus medicina, szorongás, szakmai irányelv

\section{Psychosomatic disorders and illnesses: a blind spot of medicine}

Introduction: The care of patients with psychosomatic disorders has bad efficacy. It beards hard both for the patients and the health care providers.

Objective: Review of presentrecommendations for psychosomatic symptoms and illnesses in the recent Hungarian medical protocols.

Method: A detailed evaluation of 134 medical protocols from altogether 531 protocols with closer connection with psychosomatic disorders were carried out, their diagnostic and therapeutic recommendations were analyzed. Further review of 39 (of the 134)directly related to psychosomatics was done. Investigation of psychiatric protocols for the same aspects was carried out, as well.

Results: Only a small part of the protocols contain recommendations for psychosomatic disorders. Ratios of their presence: diagnostic - direct 10.25 , indirect 23.7 , therapeutic - direct 25.64 , indirect $15.38 \%$. Efforts for prevention are only in $5.12 \%$ of the materials and $10.25 \%$ of the protocols mention a possible dual nature of the given clinical manifestation. Anxiety disorders occur only in $30.76 \%$. Psychiatric protocol directly aiming psychosomatic problems is lacking. Conclusion: Presence of psychosomatic medicine in clinical guidelines defining the conditions of successful care of patients is practically minimal. Possible explanations: confusion in approaches, lack of consensus among the psychiatric institutions, and deficiency of interdisciplinary cooperation. Both in relevant clinical research and in development of medical protocols common additive efforts are necessary for achieving a more successful care of high numbers of patients presently neglected because of the mentioned causes. Author advises some concrete steps for the solution.

Keywords: psychosomatic medicine, anxiety, medical guideline

Rajna P. [Psychosomatic disorders and illnesses: a blind spot of medicine]. Orv Hetil. 2021; 162(7): 252-261.

(Beérkezett: 2020. július 27.; elfogadva: 2020. szeptember 8.) 


\section{Rövidítések}

$\mathrm{BNO}=$ betegségek nemzetközi osztályozása; DSM = (Diagnostic and Statistical Manual of Mental Disorders) Mentális rendellenességek kórmeghatározó és statisztikai kézikönyve (a pszichiátria saját nevezéktani útmutatója); EURONETSOMA $=$ (European Network to Improve Diagnostic, Treatment and Health Care for Patients with Persistent Somatic Symptoms) Európai Hálózat a tartósan szomatikus tünetekkel küzdő betegek diagnosztikai, kezelési és egészségügyi ellátásának javítására; MUS, MUPS = (medically unexplained $/$ physical/ symptoms) orvosilag megmagyarázhatatlan /fizikai/ tünetek; NICE = (National Institute for Health and Care Excellence) Az Egészség és Klinikai Kiválóság Nemzeti Intézete SSD = (somatic symptom disorder) szomatikus tüneti zavar

A lelki-érzelmi feszültség testi jelenségek formájában történő megnyilvánulása általánosan ismert. Több közhasználatú nyelvi fordulat is világosan utal erre: „amikor megláttam, majd' elájultam/elállt a lélegzetem, elakadt a szavam, elment az étvágyam”, „felment a cukrom/vérnyomásom”, „szívidegem/gyomoridegem van”, stb. Ezek a szomatikus manifesztációk azonban számos (közöttük súlyos) betegségnek is lehetnek alapvető tünetei. A pszichogén testi jelenségeket magába foglaló klinikai szakterület a pszichoszomatikus medicina.

\section{A pszichoszomatikus medicina tág értelmezése (nevezéktani bizonytalanság)}

A test és a lélek elválaszthatatlanságának tényét senki sem vitatja. Minden súlyosabb testi történés esetén lehet a szellemi múködések, vagy az érzelmi egyensúly átmeneti megingására számítani, és fordítva. Az is nyilvánvaló, hogy a testi és lelki zavarok egyidejü tartósabb fennállás esetén egymásra klinikailag is jelentős hatást gyakorolhatnak, illetve a komorbid szomatikus és pszichiátriai beteg ellátása nehezebb. Egyes súlyos testi történéseknél a pszichiátriai szövődmény kockázata kifejezetten magas (például post stroke depresszió stb.), és a pszichoszomatikus manifesztációk súlyos akadályt jelenthetnek egyes kórképek rehabilitációja során (például ischaemiás szívbetegségek, onkológiai betegségek stb.). Ezek a klinikai kapcsolódások azonban többnyire a kórelőzményből viszonylag egyszerúen felismerhetők. Az ok-okozati irány egyértelmú, és ez meghatározza a betegellátás lépéseit.

$\mathrm{Az}$ említettektől függetlenül létezik az „elsődleges” pszichoszomatikus tünetekkel jelentkező, illetve pszichoszomatikus betegségekben szenvedő betegpopuláció. Sajnálatos, hogy nozológiai megjelenésük csupán a pszichiátria (a BNO-10 szerinti F kategória) nevezéktanára vonatkozik: egyes disszociatín zavarok (F44.4F44.9), illetve a szomatoform rendellenességek (F45.0F45.9) elnevezéssel. (Az ide tartozó betegek azonban panaszaik természetéből fakadóan elsőként biztosan nem pszichiátert keresnek fel.) Ez a tény összefüggésben állhat a szorongásos zavarok általános klinikai értelmezési nehézségeivel. Előfordulásuk ugyanis a széles populációs kutatásokban meghökkentően nagy szórást mutat $(3,8-$ $25 \%)[1]$.

\section{Az „elsődleges” pszichoszomatikus tünetek és betegségek pathomechanizmusáról}

Olyan kórállapotokról van szó, amelyek kialakulásában az adott személy szervezetének „gyengébb pontjaival” (locus minoris resistentiae) összefüggésben lelki zavarok hatására testi panaszok, tünetek lépnek fel. Alakulásuk kezdetben felismerhető kapcsolatot mutat a pszichés közérzet változásával, és általában tartósabb terhelő külső hatások nyomán erősödik fel (reaktív/szituatív/exhausztív), azaz másodlagos, következményes (pszichoszomatikus reakció). Megfelelő kezelés nélkül azonban a testi zavar állandósul, és a károsító pszichés hatás (esetleg nem is tudatosuló intrapszichés konfliktus) jelenlétével együtt halad ( $p s z i$ choszomatikus betegség függo" fázisa), majd a kifejlett szakban alakulása már nem is köthető szorosan a lelki történések jelenlétéhez (önálló pszichoszomatikus betegségek). Szerencsére nem túl gyakran, a pszichoszomatikus tünetképzés rejtett formában is megjelenhet. Egy adott szakterület legsúlyosabb betegei közé tartozhatnak azok a páciensek, akik szervi betegsége minden terápiának makacsul ellenáll, mert a terápiás hatás megítélését pszichés tényezők hatására alapbetegségükre emlékeztető tünetek (konverziós mechanizmusok BNO-10: F44.4-F44.9) torzítják. Jó példa erre az epilepsziás betegeknél kialakuló pszichogén nem epilepsziás roham.

Áttekintésemben a mindennapi betegellátásra vonatkozó irányadó hivatalos szakmai anyagban próbálom értékelni az „elsődleges” pszichoszomatikus tünetek és betegségek megjelenését, ezek ellátási ajánlásait. Mindennapi betegellátó munkám során ugyanis évtizedek óta látok e területen tömegesen „kallódó” pácienseket. Többségüknél a pszichoszomatikus betegség már több éve zajlik, és a kezelés szempontjából kedvezőtlen, előrehaladott állapotot mutat. Szakorvosi vizitek tömkelege, vizsgálati leletek súlyos halmaza jelzi a felesleges, esetleg kontraproduktív többletaktivitásokat és a sokszor egyszerú, hatékony beavatkozások égető hiányát.

Munkahipotézisem szerint egyéb okok mellett, amelyekre késöbb röviden kitérek, a pszichoszomatikus kórfolyamatok ellátására vonatkozó ajánlások hiánya, azaz valójában e betegpopuláció nem tudatos „elrejtése” is vezethet a felsorolt káros következményekhez. A gyakorlatban ez azzal jár, hogy a pszichoszomatikus beteg döntö többsége panaszával - reménytelenül - a szomatikus medicina útvesztöjében köröz.

A téma (egyéni és társadalmi) jelentőségét növeli, hogy kifejezetten gyakori, szinte minden beteg vonatkozásában több szakmát érintő panaszokról, tünetekről, szenvedő és sokszor reményvesztett páciensek tömegéről van szó. Ennek ellenére, a nemzetközi szakirodalom is szúkösnek, klinikai epidemiológiai jelentőségéhez viszonyítva csekélynek mondható. Például a NICE adatbázis- 
ban történő keresés (2020.08.04-én) a kb. azonos epidemiológiai erősségű „pánik-zavarra” 1407, a „szomatoform/szomatizáció” kifejezésre pedig csupán 292 találatot eredményezett.

A pszichoszomatikus betegségekkel kapcsolatos hazai kutatások is magukon viselik az említett terheket. Csak egyetlen példa erre: miközben a 2010-es évek elején elvégzett nagyívư hazai egészségkutatás (Hungarostudy) alapján is egyértelmú a kapcsolat a prolongált stressz, az alvászavarok és a diabetes között [2], egy friss, az alapellátásban elvégzett kockázatalapú praediabetes-szűrést elemző közleményben ezek a tényezők meg sem jelennek [3]. Dolgozatomat gondolatébresztőnek, vitaindítónak szánom.

\section{Módszer}

A klinikai szakterületek vezető testületei (szakmai kollégiumok) a Bizonyítékon alapuló orvoslás kutatási pilléreit a mindennapi betegellátók számára betegség-, illetve ellátás-centrikus módon, egyszerüsített és összevont (ajánlásos) formában a Szakmai irányelvek segítségével rögzítik. Ezeket vettem én is alapul. Elemzésem anyagához a következőképpen jutottam el. A szakirodalom és saját tapasztalataim alapján meghatároztam a leggyakoribb/legjelentősebb pszichoszomatikus természetű panaszokat (1. táblázat) [4-10]. Az Egészségügyi Szakmai Kollégium Tagozatai és Tanácsai honlapján [11] 2020. július 11-én elérhető 531 irányelv közül a táblázatokban szereplő klinikai meghatározások szerint kiemeltem, gondosan elolvastam, és az alábbiakban ismertetett szempontok mentén értékeltem azt a 134 dokumentumot, amelynek betegellátási területén témájuk/címük/ tartalmuk alapján pszichoszomatikus betegek jelentősebb számban előfordulhatnak. E halmazból kiemeltem azt a 39 irányelvet, amelynek témája kifejezetten kapcsolódik pszichoszomatikus jelenségekhez. Végül hasonló módon elemeztem a Pszichiátriai és Pszichoterápiás, illetve a Gyermek- és Ifjúságpszichiátria és Addiktológiai Tagozat $15+11$ irányelvét. (A harmadik, a Klinikai szakpszichológia, pszichoterápia, klinikai szakpszichológia szakági tagozat nem készített anyagot.)

\section{Értékelem}

1. hogy a kiemelt ajánlásokban milyen arányban és szinten szerepelnek a pszichoszomatikus folyamatokra vonatkozó szakmai megjegyzések,

2. hogy az egyértelmúen „pszichoszomatikus-közeli” témák irányelveiben milyen módon jelenik meg ez az etiológia,

3. a pszichoszomatikus medicina jelenlétét és esetleges ellátási ajánlásait a pszichiátriai tagozatok irányelveinek sorában,

4. hogy a pszichoszomatikus kórállapotok milyen arányban rendelkeznek önálló szakmai irányelvekkel,

5. és kiemelek a szövegekből néhány megjegyzést a pszichoszomatikus medicinával összefüggésben.

1. táblázat |Az alapellátásban megjelenő pszichoszomatikus betegek leggyakoribb panaszai a [4] és [5] hivatkozás alapján, módosítva

\begin{tabular}{lll}
\hline Tünetek (kombinációk) & Szindrómák* & Szakterület \\
\hline $\begin{array}{l}\text { Puffadás, székrekedés, hasmenés, hasi fájdalom, } \\
\text { görcs }\end{array}$ & $\begin{array}{l}\text { Irritábilisbél-szindróma, funkcionális } \\
\text { dyspepsia, gastroparesis [6] }\end{array}$ & Gasztroenterológia \\
\hline $\begin{array}{l}\text { Fáradékonyság (elsósorban terheléses) fokozott } \\
\text { pihenési igénnyel }\end{array}$ & $\begin{array}{l}\text { Krónikusfáradtság-szindróma, cardiomyopa- } \\
\text { thia, myalgiás encephalomyelitis }\end{array}$ & $\begin{array}{l}\text { Infektológia, endokrinológia, reumatológia, } \\
\text { fájdalomambulanciák }\end{array}$ \\
\hline Krónikus alvászavar & Pszichofiziológiai insomnia & Neurológia, alváscentrum \\
\hline Krónikus hátfájás & $\begin{array}{l}\text { Krónikus nem onkológiai hátfájdalom } \\
\text { szindróma [7] }\end{array}$ & Reumatológia, ortopédia \\
\hline Fejfájás, émelygés, hányinger, szédülékenység & $\begin{array}{l}\text { Agyrázkódási szindróma, tenziós fejfájás, } \\
\text { atípusos migrén }\end{array}$ & Neurológia, baleseti ambulancia \\
\hline Derékfájás, fájdalmas szex, fájdalmas periódusok & Krónikus medenceövi fájdalom szindróma & Nógyógyászat, urológia, reumatológia \\
\hline Izomfájdalom, fonákérzések, lokális érzékenység & $\begin{array}{l}\text { Fibromyalgia, krónikusfájdalom-szindróma, } \\
\text { benignus fasciculatiós szindróma [8] }\end{array}$ & Reumatológia \\
\hline Mellkasi fájdalom, szívritmuszavarok & Nem cardialis mellkasi szindróma & Kardiológia, pulmonológia \\
\hline Krónikus lokális fájdalom & Komplex regionális fájdalom szindróma [9] & Neurológia, reumatológia \\
\hline Légszomj, nehézlégzés & Hyperventilatiós szindrómák & Kardiológia, pulmonológia \\
\hline Ájulásérzés, ájulás & Syncope, vasovagalis collapsus & Kardiológia, neurológia \\
\hline Légúti, nyelési panaszok, köhögés & $\begin{array}{l}\text { Krónikus légúti gyulladások, krónikus } \\
\text { refluxbetegség }\end{array}$ & $\begin{array}{l}\text { Fül-orr-gégészet, pulmonológia, gasztro- } \\
\text { enterológia }\end{array}$ \\
\hline Viszketés, szaglási-ízérzési zavarok & Többszörös kémiai érzékenység & Bórgyógyászat, allergológia \\
\hline Állkapocsfájdalom, rágási zavarok & Krónikus temporomandibularis zavarok [10] & Fogászat, szájsebészet \\
\hline
\end{tabular}

*A panaszok hátterében álló pszichoszomatikus vonatkozású kórismék (a kevésbé ismertek irodalmi hivatkozással). 


\section{Eredmények}

A szakmai irányelvekben szereplő pszichoszomatikus vonatkozású utalásoknak az alábbiakat tekintettem:

- A diagnosztikai fejezetben a pszichés noxa, mint etiológia vagy provokáló tényező közvetlenül megjelenik.

- A diagnosztikai fejezetben a pszichés hatás közvetve (nem pszichiátriai terminussal) jelenik meg.

- A terápiás fejezetben a pszichés zavar kezelése szerepel az ajánlásban.

- A terápiás fejezet a pszichés zavar kezelésére közvetett utalást tartalmaz.

- A prevenciós fejezet tartalmaz utalást pszichés noxák kiiktatására.

- A dokumentum tartalmazza a szorongás kifejezést.

- A dokumentum tartalmaz pszichiátriai komorbiditásra utaló megjegyzést.

- Továbbá megállapítottam azoknak az irányelveknek az arányát, amelyek a fentiekból legalább hármat tartalmaztak.

Nem ragaszkodtam pontos, hivatalos pszichiátriai nevezéktani kifejezésekhez, mint szomatoform/szomatizációs zavar, konverzió stb. Például a szorongás viszonylag pontos fogalmán kívül elfogadtam (az egyébként helytelen és félrevezető) stressz kifejezést, illetve a pszichés okok említését is.

\section{Hiányos irányelvek}

$\mathrm{Az}$ ismertetett utalások előfordulása a 134 dokumentumra vonatkozóan az 1 ábrán, ezen belül a leginkább érintett 39 irányelvet illetően pedig a 2. ábrán látható.
A vizsgált tartalmi elemek előfordulásának kifejezetten alacsony arányai önmagukért beszélnek.

Ha azzal a - szakmailag nyilván vitatható - sommás meghatározással jellemeznénk a pszichoszomatikus jelenségek elfogadható szintû megjelenését a hivatalos szövegekben, hogy az értékelt adatok közül legalább 3 féle megjelenés szerepel, az eredmény akkor is lehangoló. A pszichoszomatikus betegségekhez legközelebb álló 39 dokumentum közül mindössze $6(15,38 \%)$ teljesíti ezt az elvárást!

\section{Hiányzó irányelvek}

A pszichoszomatikus betegellátás duális feladatának egyik obligát résztvevője a pszichiátria, a másik pedig az a szúkebb (szomatikus) szakterület, amelyhez az adott tünet besorolható. Mivel a pszichoszomatikus karrier során a „pszicho” az elsődleges (primum movens), kiemelten fontos, hogy a mára már megkettőződött (gyermek és felnőtt) pszichiátria irányelvei között a pszichoszomatikus zavarok hogyan jelennek meg. Az előző fejezetben taglalt módon elemzés alá vetettem ezeket is. (A szorosabb társszakmák közül az addiktológiát az általános listába soroltam, a klinikai szakpszichológia tagozat pedig nem jelentetett még meg útmutatót.) A honlapon 14 felnőtt és 11 gyermekpszichiátriai irányelv olvasható. 5 téma pszichoszomatikus szempontból irreleváns. A maradék 20-ban szereplő pszichoszomatikus utalások összesítését a 3. ábra tartalmazza. Az utalások előfordulási arányszámai azonban megtévesztőek. Alig hihető, de mégis igaz: a pszichoszomatikus tünetek és betegségek (BNO F44, ill. F45) ellátására vonatkozóan nincsen

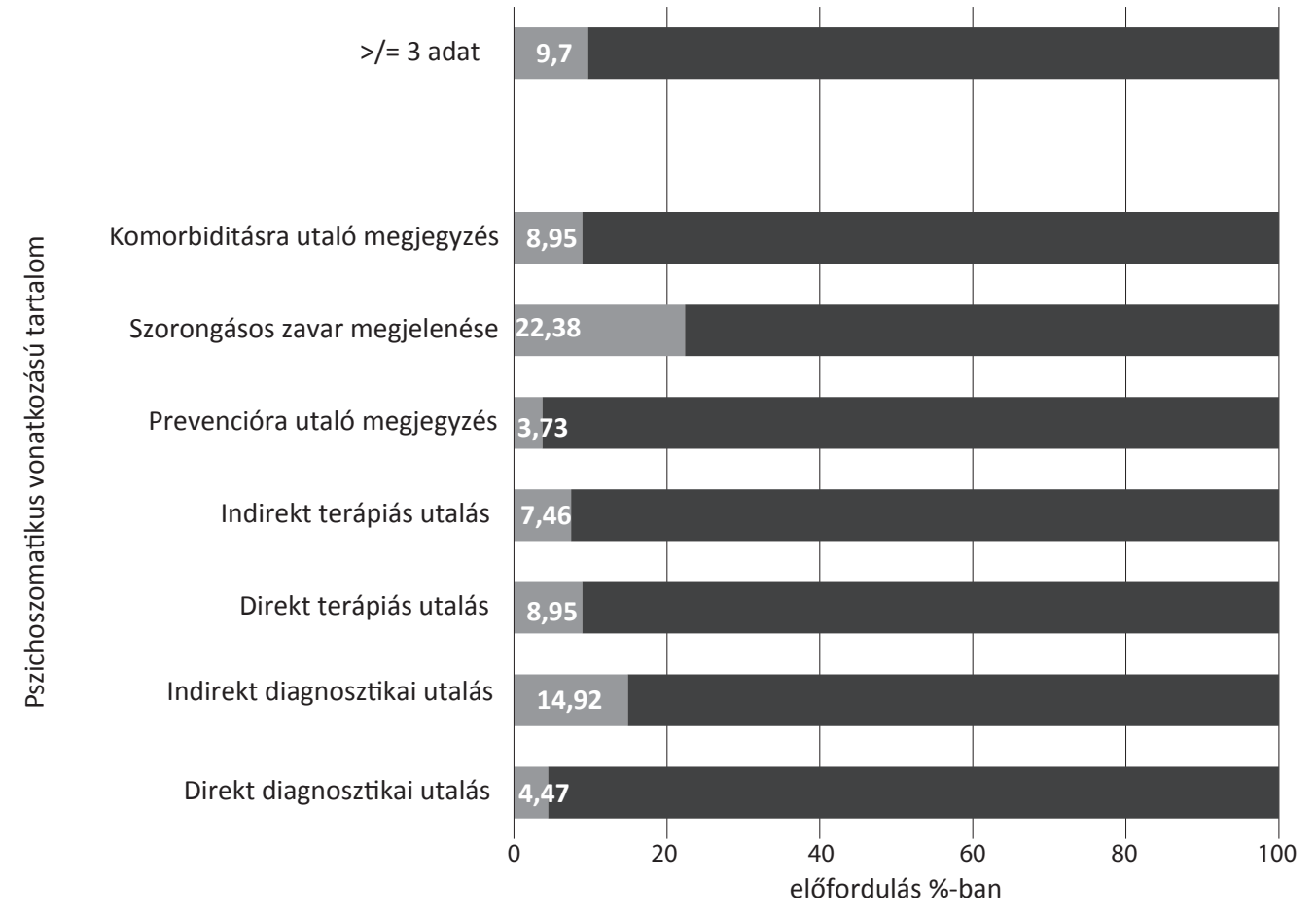




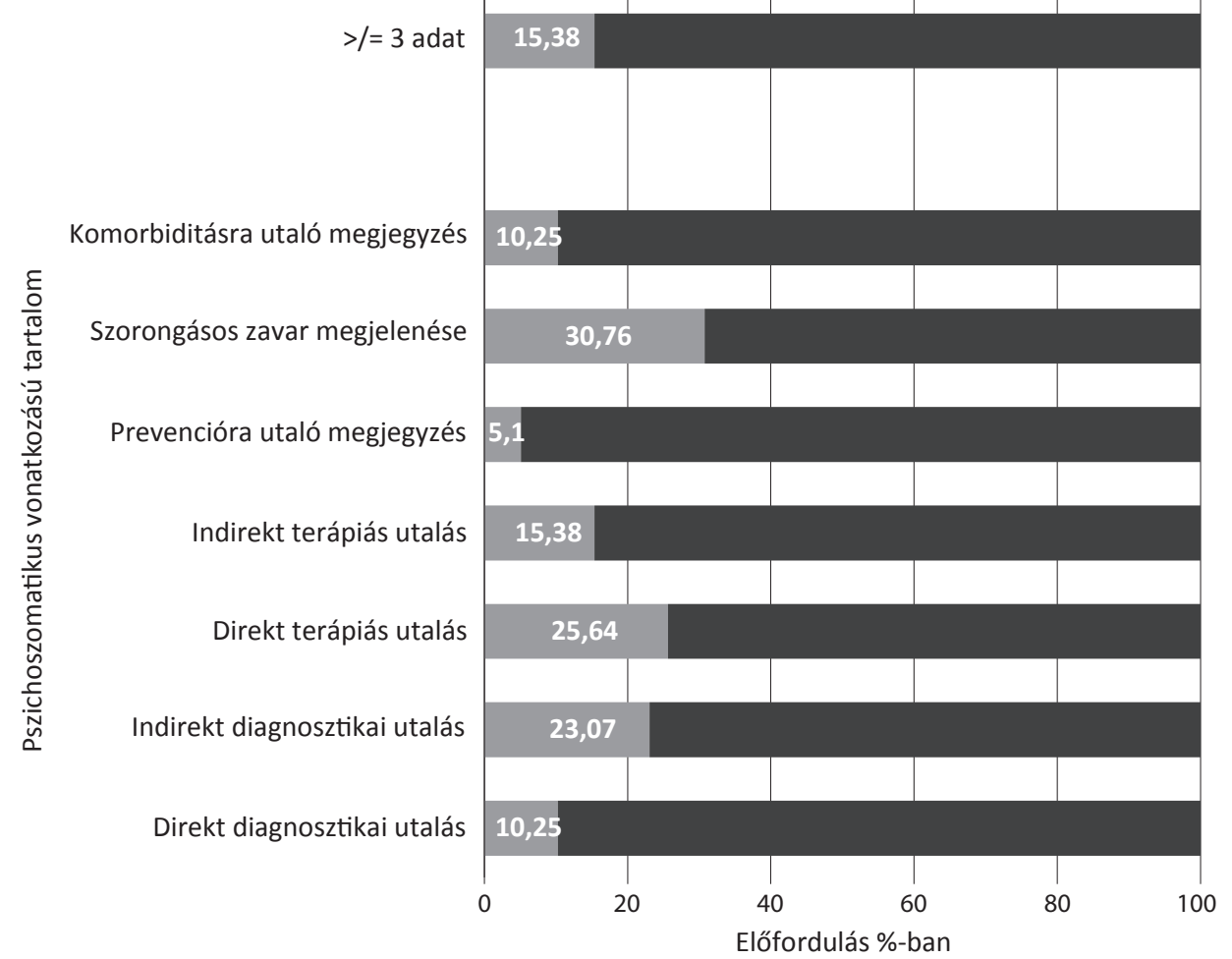

2. ábra

| Szorosabb pszichoszomatikus vonatkozású szakmai irányelvek néhány releváns adata

szakmai ajánlás! Az égető hiányt csak kis fokban enyhíti, hogy a pszichoszomatikus zavarhoz igen gyakran társuló szorongásos zavar (F40-42), insomnia (F51), valamint a szintén jelentős komorbiditást mutató alkoholbetegség (F10) témájában készült szakmai anyag.

\section{Szemléleti zavarok}

Annak a meghökkentő ellentmondásnak, amely a pszichoszomatikus betegek tömeges jelenlétében és az ellátásukra vonatkozó protokollok viszonylagos hiányában fogalmazható meg, nyilvánvaló szemléleti okai vannak. Az ajánlásokban szereplő néhány megjegyzés világosan utal erre. E tanulmánynak nem lehet célja konkrét szakmai dokumentumok minősítő elemzése, ezért az alábbi tartalmi elemeket azonosítás nélkül említem:

\section{Dichotomia}

- Egyes krónikus gyulladásos folyamatokkal magyarázott szindrómák hátterében - nem kellő terápiás eredmény esetén - a betegek többségénél (!) pszichoszomatikus folyamat feltételezhető. Az egyik vonatkozó anyagban az alábbi olvasható: „A krónikus gyulladás panaszokat okozó volta egyértelmúen nem bizonyított, és emiatt a terápiás teendők is bizonytalanok." Így az irányelv a továbbiakban ezzel az állapottal nem is foglalkozik.

- az egyik leggyakoribb multidiszciplináris pszichoszomatikus jelenség ellátásának precíz, a beteg megjele- nési helyszínei szerinti ajánlása „a pánik-szindróma” (azaz pszichogén tünetképzés) kizárása utáni teendőkre vonatkozik.

\section{Mereven értelmezett „illetékességi” kérdések}

- az egyik fájdalom-szindrómára vonatkozó irányelv annak ellenére sem tér ki az esetleges pszichoszomatikus eredetre, hogy megállapítja: „A családorvosi rendelőben gyakran hasonló panaszokkal jelentkező betegek esetében a nem ... (az irányelv témájának megfelelő) ... fájdalom fordul elő legsứrübben.”

\section{A pszichoszomatikus tünetekkel/páciensekkel kapcsolatos (nem-tudatos) bagatellizálás - ellenérzés - elháritás}

- Miközben az egyik ajánlás kiemeli, hogy az adott biológiai történés „ismeretlen eredettel” történő diagnosztikus lezárása többlet vizitekhez és költséges (neurológiai képalkotó) eszközök túlzott igénybe vételéhez vezet, az alábbi nem éppen ösztönző megjegyzést tartalmazza: „Időigényes explorációval csökkenthetjük a fel nem ismert pszichiátriai eredetú esetek arányát.”

- Egy igen gyakori, sok esetben pszichoszomatikus tünet hatékony fizioterápiáját csak nőgyógyász vagy neurológus javasolhatja, pszichiáter nem.

- Egy máig nem teljesen tisztázott pathomechanizmusú, igen gyakran pszichés tünetekkel szövődő speciális 
fájdalomszindrómát hatékonyan lehet kezelni pszichotróp gyógyszerekkel. Az irányelv szerint azonban a beteget tájékoztatni kell, hogy a szert fájdalomcsillapitóként kapja.

- Egy másik, többségében pszichiátriai alapbetegséghez kapcsolódó fájdalomszindróma egyébként részletes tárgyalását követően a betegtájékoztatás során az ajánlás szerint a beteget fel kell világosítani, hogy „nem egyszerúen csak »lelki « ... panaszról van szó”.

- A gyulladásos folyamatok korábban említett krónikus formáinak pszichoszomatikus természetét a vonatkozó irányelv annak ellenére nem tárgyalja, hogy megállapítja: végül csak a betegek 10-15\%-ánál igazolható a konkrét infekciós (bakteriális) etiológia.

\section{A pszichoszomatikus medicinával kapcsolatos kellö alapismeretek hiánya}

- Az egyik irányelv pszichiátriai kivizsgálást abban az esetben tart szükségesnek, ha a betegnek „sok szomatikus panasza van, és a vizsgálatok során idegesség, izgatottság, anxietas, pánikszindróma, vagy más pszichiátriai rendellenességre utaló jelek" észlelhetők.

- Miközben egy speciális fájdalomszindróma első számú gyógyszerei pszichiátriai alapkészítmények, és a dokumentum több helyütt is kitér pszichés kísérőjelenségekre, ezeket kizárólag következményesnek minősíti.

\section{Elégtelen szakmaközi együttmúködés}

Az irányelvek követelménye, hogy megalkotásukban az összes érintett szakterület illetékesei vegyenek részt. A 2013.01.01. után készült irányelvekben már a fejlesztést végző Szakmai Kollégiumi Tagozat(ok) mellett fel kell tüntetni a véleményező intézményeket is. A 2. ábrán értékelt 39 dokumentum közül sajnos csupán 6 készült ebben az időszakban (közülük kettőt véleményeztek pszichiátriai szakemberek is), ezért ez a feltétel részletesebben nem vizsgálható. A tartalom alapján azonban egyértelmú, hogy pszichoszomatikus szempontú egyeztetés csak elenyésző arányban történhetett.

\section{Megbeszélés}

Amint látjuk, a dolgozat tárgyát képező pszichiátriai szakfogalmak ritkán szerepelnek a betegellátás eljárási dokumentumaiban. Érdekes módon azonban a szomatizáció kifejezés három helyen is megjelenik: (1) A házi gyermekorvosok kompetencia listáján, valamint (2) a háziorvosi hatásköri listán a pszichiátriaiak sorában szerepel a „szomatizáció gyanújának felismerése”. Az elvárással teljes mértékben egyet lehet érteni. A kérdés csupán az, hogy a kollégák személyes tapasztalataikon túlmenően milyen tudományosan igazolt ajánlások alapján járjanak el? (3) Paradox módon egy pulmonológiai irányelv is nyilatkozik arról, hogy az adott kórfolyamat „elsődlegesen” (?) nem pszichoszomatikus betegség. A témát azonban a továbbiakban nem tárgyalja.

\section{A pszichoszomatikus betegségek egészségügyi és társadalmi jelentôsége}

A házi- és szakorvosi betegellátásban jelentkező pszichoszomatikus tünetek és betegségek aránya a szakirodalomban erôs szórást mutat, mert nem könnyú vizsgálni. A háziorvosi vizitek összességét 10-35\%-ban ilyen betegek kötik le [12]. A tömeges jelenlét mellett a kórállapot viszonylagos rejtettsége is köztudott. A háziorvosi vizitekre gyakrabban jelentkezők 21\%-a krónikus szomatizációs zavarban szenved [13]. A szakma számára sem ismert, hogy gyakorisága a szorongásos zavarokkal és a depresszióval azonos [14].

Kevés kutatás foglalkozik közvetlenül pszichoszomatikus tünetekkel. 2015-ben Haller és mtsai metaanalízist végeztek az alapellátásban jelentkező szomatoform, illetve „organikus alapon nem magyarázható" tünetek előfordulásáról [15]. Csaknem ezer közlemény alapján gyakoriságukat meglepően magasnak találták. A DSM-IV, illetve BNO-10 szerint meghatározott pszichoszomatikus betegség(ek) jelenléte összességében 26,2\% volt. A vizitek során legalább egy ilyen jellegü panaszt a betegek 4049\%-a említett! Sattel és mtsai is [16] közel hasonló eredményre jutottak: a háziorvosi praxisban jelentkező páciensek közül minden ötödik pszichoszomatikus beteg!

\section{A pszichoszomatikus klinikai jelenségek azonositási hiánya a nem pszichiátriai/ addiktológiai/klinikai pszichológiai vonatkozású irányelvekben}

Az e körbe tartozó betegek tünetei szinte kivétel nélkül lehetôvé teszik, hogy valamilyen szervi betegség diagnózisát már az első megjelenéskor megkapják (esetleg atípusos megjelenéssel: BNO-10 90-es végződésú kódok). Ezzel olyan futószalagra kerülnek, amely a további lépéseket az orvos számára látszólag egyszerúsíti: az adott klinikumra/betegségre vonatkozó diagnosztikus vizsgálati protokoll, majd szomatikus terápia (sokszor mútéti beavatkozást is magába foglalva). A kezelés eredménytelensége megjósolható: a felesleges vizsgálatok ismétlése, polypragmasia, sok esetben a kórfolyamat tünetváltását követően az előbb felsoroltak elvégzése egy újabb szomatikus részterületen.

Érthetô, hogy a pszichoszomatikus betegségeket klinikai komplexitásuk miatt nehéz egyetlen szakterületre besorolni. Mivel a kifejezés első része két (egymást kissé át is fedő) szakterülethez (pszichiátria/klinikai pszichológia), a második pedig „az összes többihöz” kapcsolódik, a megnevezés maga is megtévesztő lehet (vö. a bevezetőben leírt tág értelmezési körrel). A kutatások 
során ezért gyakran a betegeket „többszörös, orvosilag nem magyarázható tünetekben" (medically unexplained /physical/ symptoms MUS, MUPS) [4, 17-20], vagy „szomatikus tüneti zavarban” (somatic symptom disorder) [21] szenvedőkként nevezték meg. Az egyik legfrissebb kutatásban pedig a „differenciálhatatlan szomatikus zavarokban” („undifferentiated somatic disorders”) elnevezés szerepel [22]. Az EURONET-SOMA csoport kutatói a pszichoszomatikus medicinát új nevezéktani alapra helyeznék [23]. Véleményük szerint erre azért van szükség, mert l) új ismeretek születtek a kórképek etiológiáját illetően, 2) a betegek kezelése megosztott a szakterületek között, 3) a jelenlegi klasszifikációk nem tudják kezelni ezen folyamatok plaszticitását és súlyosságát, 4) a jelenlegi kezelési protokollok nem tartalmaznak megfelelő partnerkapcsolatot a beteggel és 5 ) nincs megfelelő, tömeges ellátást biztosító rendszer (és kutatási irányzat) a pszichoszomatikus páciensek számára. Az általuk javasolt funkcionális szomatikus zavarok (functional somatic disorders) spektrum „neutrális” természetú, azaz bevezetésével ezeket a pácienseket a továbbiakban már nem szükséges feltétlenül besorolni sem szervi, sem mentális betegségkategóriába.

\section{A pszichiátria és társterïletei hallgatnak}

A pszichoszomatikus beteg szerteágazó tüneteinek közös gyökereit kétségtelenül a pszichés zavarokkal foglalkozó szakterületeken [saját becslésem szerint a BNO nevezéktanát alapul véve kb. 70-90\%-ban a szorongásos spektrumban, ezen belül elsősorban a szomatoform (F45), illetve kisebb mértékben a disszociatív zavarok körében (F44), 10-30\%-ban pedig a viselkedési (F5), illetve a személyiségzavarok területén (F6)] találjuk meg. A nagyfokú nevezéktani szórás érthetően nehezíti mind a célzott kutatást, mind az egységes hatékony ellátási ajánlások kidolgozását. Ez a felismerés vezethetett arra, hogy a legújabb pszichiátriai nevezéktárban (DSM-V) a kategória már új néven szerepel (Somatic Symptom Disorder - SSD). A szakmaközi összefogást és egyáltalán a kompetenciák meghatározását feltehetően tovább bonyolítja, hogy már a pszichés alapzavarok tekintetében is legkevesebb három szakterület érintett (19. Gyermek pszichiátria és addiktológia, 31. Klinikai szakpszichológia és pszichoterápeuta klinikai szakpszichológus és 48. Pszichiátria, pszichoterápia).

Ha tehát meggondoljuk, hogy egy pszichoszomatikus ellátási irányelv megalkotásához a fenti 3 szakterület grémiumainak az adott testi klinikai jelenségekben illetékes alap- és társszakmai kollégiumok illetékes szakmai tagozataival és tanácsaival kellene egy, a mai meglehetósen mereven formalizált követelményeknek megfelelő terjedelmes szakmai javaslatot kidolgoznia, az ösztönös elhárító reakciók érthetőbbé válnak. Ezek játszhatnak közre abban, hogy a pszichoszomatikával kapcsolatosan még a pszichiátriai dokumentumok is csak 5-40\%-ban tartalmaznak ajánlásokat, és a szorongásos alap hangsúlyozása sem teljeskörü (80\%) (3. ábra).

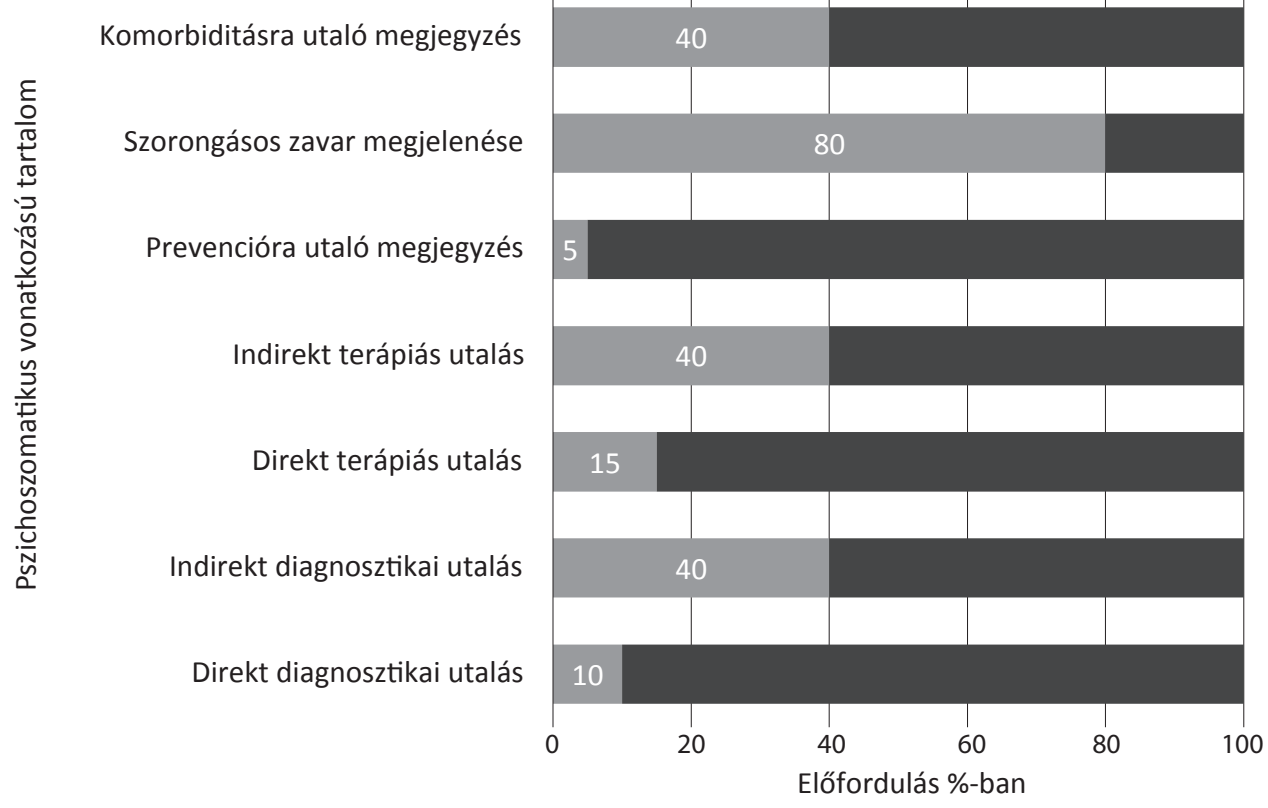

3. ábra $\mid$ Pszichoszomatikus vonatkozás megjelenése a pszichiátriai szakmai irányelvekben 
A pszichoszomatikus betegek ellátásának javításával az alapellátás biztosan hatékonyabbá válik [24]. Ezért ajánlások kidolgozására már több erőfeszítés is történt. A Heidelbergi Egyetem pszichoszomatika tanszékének csapata kidolgozta az ún. S3 irányelvet. 29 illetékes orvosi és pszichológiai társaság képviselői négyezret meghaladó speciális válogatású közlemény elemzésével, két online és három szervezett konszenzusmegbeszélés során hozták létre [25]. Az anyag messzemenően alkalmas arra, hogy nemzeti/helyi szinten a legfontosabb teendőket meghatározzák és az ellátás hatékonyságát és minőségbiztosítását javítsák, az eltelt évek során jelentősebb felhasználásáról, fejlesztéséről mégsem található közlés. A hatályos irányelvek fooleg az alapellátást célozzák [2628]. Olyan részletes ajánlás is létezik, amely nem a kezelőorvosok, hanem a szolgáltató intézmények képviselői számára készült [4].

\section{A jelenlegi gyakorlat nem költséghatékony és nem „páciens-barát”}

Sőt, a mindennapi gyakorlat inkább „ellátó-barátnak” tünhet: a pszichoszomatikus beteg testi panaszaival kapcsolatos „rutin” vizsgálatainak elvégzése, egy, legfeljebb két szakorvosi konzultáció, javaslatukra néhány további vizsgálat, majd a testi panaszokra vonatkozó egyszerú (tüneti) terápia. Valójában azonban nem az, hiszen az eredménytelenség miatt a folyamat ismétlése felesleges vizitek tömegével és súlyos anyagi és egyéb terheket jelentő hiábavaló vizsgálatokkal terheli meg az ellátó rendszert. A pszichiátriai konzultáció sok esetben inkább „ultima ratio”. Mindenek felett, az előbbieknél is károsabb következmény a beteg szenvedésének rögzülése, elégedetlensége, a betegségek előrehaladásával pedig életminőségének, -kilátásainak romlása.

Nem hiszem, hogy tévedek: a krónikus pszichoszomatikus betegek többsége ma már (kombinációban vagy kizárólag) nem igazolt hatású diagnosztikai és terápiás eszközöket használ, azaz jelentős részük elhagyta a hivatalos ellátórendszert. A súlyos költségeken túl a választás hatékonysága is vitatható. Bátran kijelenthetjük: a Charite egyetem CAMbrella munkacsoportjának 2010-es víziója arról, hogy mit kell tudniuk az európai pácienseknek és kezelőiknek 2020-ban a komplementer és alternatív medicína tudományos értékéről, sajnos nem valósult meg [29].

Az ún. Delphi-tanulmányban 2016 és 2017 között háromfordulós konszenzus program keretében határozták meg a pszichoszomatikus medicinával kapcsolatos kutatások nyolc prioritását. Ezek (rövidítve): 1) diagnosztikai profilok kialakítása, 2) hatékony terápiák kifejlesztése, 3 ) validálható eszköztár kialakítása, 4) a betegek jobb felismerését szolgáló kutatások, 5 ) módszertani kutatások a zajlást módosító terápiás beavatkozások hatásának igazolására, 6) célzott genetikai kutatások, 7) kutatások a személyre szabott terápiák fejlesztésére, 8 . az ellátás kompetencia szintjeinek meghatározása [30].

\section{A pszichoszomatikus medicina hazai „belyzetbe hozásának” lehetöségei}

A megoldás kialakításához, az ahhoz szükséges kapacitások és anyagi feltételek becsléséhez szükség lenne a vonatkozó betegek arányának, a mindennapi alap- és szakellátásokban történő megjelenésének ismeretére. Ehhez egy, a szakgrémiumok által összeállított rövid szưrőkérdőív bevezetésére lenne szükség. A következő lépés az általános, a pszichoszomatikus karriert feltáró alapjelenségek ismeretében a beteg aktuális panaszának megfelelő, azonban megfelelő önmérséklettel kialakított szakorvosi diagnosztikai modell lehetne. (Azaz például az adott tünethez, vagy betegséghez tartozó irányelv „kötelező” fejezete lehetne a „pszichoszomatikus karrier mellett jelentkező tünetek ellátása”.) A jelenlegi gyakorlattól eltéróen ez a modell limitálná a szomatikus vizsgálatok számát (a kontrollvizsgálatokat illetően is), illetve mind diagnosztikai, mind terápiás szempontból előbbre helyezné a pszichiátriai-pszichoterápiás megközelítést. E tekintetben a digitális diagnosztikai és egyéb intervenciós lehetóségeket is fel kell használni [31, 32].

Alapvető kérdés, hogy a jelenlegi hazai pszichiátriai ellátó rendszer terhelhető-e a pszichoszomatikus betegek gondozásával. A nemleges válasz borítékolható. Tehát a kezelést az alapellátásban célszerü megoldani [33]. Ehhez azonban biztosítani kell a rövid pszichiátriai konzultációk és hatékony célzott visszajelzések rendszerét [34]. Továbbá a háziorvosok alapvető (és a hiedelmekkel ellentétben időráfordítás/terápiás haszon szempontjából is előnyös) pszichoterápiás jártasságát is erősíteni kellene a legegyszerúbb módszerek elterjesztésével [4, 35, 36]. Ennek jelenleg az a fő akadálya, hogy a szóba jövő és már bizonyított intervenciós módszerek (elsősorban a kognitív-viselkedésterápia [22, 37-40]) ismertsége szúkös. A farmakoterápia (hatékonyságára egyre erősebbek a bizonyítékok [41, 42]) egyszerúbb alkalmazása céljából pedig a kezelőorvosokat a vonatkozó pszichotrop szerek rendelésében az emelt támogatás jogkörével kellene felruházni.

Az a házi- vagy szakorvos, aki egy bonyolultabb pszichoszomatikus beteget „önállóan” meggyógyít, vagy állapotában tartós egyensúlyt teremt (rehabilitál, azaz biztosítja tartós munkaképességét [43]), sikerélményhez jut, küzd a saját kiégése ellen is. Aktivitása költséghatékony, javítja az egészségügyi ellátás minőségét, hozzájárul az egészségügy reputációjának visszaállításához. Végül, de nem utolsósorban: a pszichoszomatikus medicinában eredményt csak megfelelő motiváció és partner szintű orvos-beteg kapcsolat mellett lehet elérni. A bármely okú beavatkozás sikeréhez szükséges partneri viszony kialakulásához a pszichoszomatikus betegek komplex ellátását szolgáló erőfeszítések modell-értékú példát nyújthatnak. 


\section{A jelen tanulmány föbb gyengeségei}

1. A szakmai irányelvek sem elméletben, sem gyakorlatban nem ölelik fel a betegellátás gyakorlati igényeit. A napi rutinmunka során - a szakmai grémiumok hallgatólagos beleegyezésével - a kezelöorvost inkább a tapasztalatai irányítják.

2. Több párhuzamosan elérhető azonos témájú protokoll is bekerült az anyagba. A duplikációkat azért tartottam meg, mert néhány esetben a korábbi változat tartalmazott (több) közvetett pszichoszomatikus természetű utalást.

3. A dokumentumok többségének érvényességi ideje lejárt.

4. Néhány kivételtől eltekintve az irányelvek szerkezetében alapvető rendszerhiba vonul végig. A betegek ugyanis (az első alkalommal biztosan) nem már meghatározott kórismével, hanem csupán egy vagy több panasszal fordulnak orvoshoz. Ezek alapján kell a tünetek együttesét meghatározni (szindróma), végül pedig a járulékos adatok figyelembevételével lehet az összesítő diagnózishoz jutni, terápiás döntéseket, zajlásra, kimenetelre vonatkozó becsléseket tenni. Ezzel szemben a szakmai irányelvek gyakorlatilag már végleges kórismével rendelkező betegek felismeréséről és további ellátásáról szólnak, ezért a pszichoszomatikus csoport döntő többsége - az atípusos klinikai jegyek miatt - a differenciáldiagnosztikai szưrés szakában kiesik.

Anyagi támogatás: A közlemény megírása, illetve a kapcsolódó kutatómunka anyagi támogatásban nem részesült.

A szerző a cikk végleges változatát elolvasta és jóváhagyta.

Érdekeltségek: A szerzőnek nincsenek érdekeltségei.

\section{Köszönetnyilvánítás}

A szerző hálásan köszöni a kézirat lektorálását végző Döme Péter $d r$. értékes észrevételeit és javaslatait, amelyek segítségével érthetőbbé váltak a dolgozat szemléleti alapjai és a fó klinikai üzenete. (A Szerkesztőség a lektor hozzájárulásával adta meg a nevét a szerzőnek.)

\section{Irodalom}

[1] Remes O, Brayne C, van der Linde R, et al. A systematic review of reviews on the prevalence of anxiety disorders in adult populations. Brain Behav. 2016; 6: e00497.

[2] Vincze Á, Kertész L, Czeglédi, E. The relationship between diabetes, stress and sleep problems in the light of the Hungarostudy 2013 research data. [A diabetes, a stressz és az alvásproblémák kapcsolata a Hungarostudy 2013 kutatás adatainak fényében.] Orv Hetil. 2019; 160: 1872-1880. [Hungarian]

[3] Galvács H, Szabó J, Balogh Z. Risk-based prediabetes screening in a rural general practice - oral glucose tolerance test or glycated hemoglobin? [Kockázatalapú praediabetesszúrés egy vidéki család- orvosi praxisban - orális glükóztolerancia-teszt vagy glikált hemoglobin? ] Orv Hetil. 2019; 160: 1976-1983. [Hungarian]

[4] Joint Commissioning Panel for Mental Health. Guidance for commissioners of services for people with medically unexplained symptoms. Available from: https://www.jcpmh.info/wp-content/uploads/jcpmh-mus-guide.pdf [accessed: July 11, 2020].

[5] Finley CR, Chan DS, Garrison S, et al. What are the most common conditions in primary care? Systematic review. Can Fam Physician 2018; 64: 832-840.

[6] Woodhouse S, Hebbard G, Knowles SR. Psychological controversies in gastroparesis: a systematic review. World J Gastroenterol. 2017; 23: 1298-1309.

[7] Hoffman BM, Papas RK, Chatkoff DK, et al. Meta-analysis of psychological interventions for chronic low back pain. Health Psychol. 2007; 26: 1-9.

[8] Blackman G, Cherfi Y, Morrin H, et al. The association between benign fasciculations and health anxiety: A report of two cases and a systematic review of the literature. Psychosomatics 2019; 60: 499-507.

[9] Birklein F, Dimova V. Complex regional pain syndrome up-todate. PAIN Rep. 2017; 2: e624.

[10] Song YL, Yap AU, Türp JC. Association between temporomandibular disorders and pubertal development: a systematic review. J Oral Rehabil. 2018; 45: 1007-1015.

[11] National Healthcare Service Center. Professional guidelines. [Állami Egészségügyi Ellátó Központ. Szakmai irányelvek.] Available from: https://kollegium.aeek.hu/Iranyelvek/Index [accessed: July 11, 2020]. [Hungarian]

[12] Hoedeman R, Blankenstein AH, van der Feltz-Cornelis CM, et al. Consultation letters for medically unexplained physical symptoms in primary care. Cochrane Database Syst Rev. 2010; 12: CD006524.

[13] Smits FT, Wittkampf KA, Schene AH, et al. Interventions on frequent attenders in primary care. A systematic literature review. Scand J Prim Health Care 2008; 26: 111-116.

[14] Konnopka A, Schaefert R, Heinrich S, et al. Economics of medically unexplained symptoms: a systematic review of the literature. Psychother Psychosom. 2012; 81: 265-275.

[15] Haller H, Cramer H, Lauche R, et al. Somatoform disorders and medically unexplained symptoms in primary care. Dtsch Arztebl Int. $2015 ; 112: 279-287$.

[16] Sattel H, Schaefert R, Häuser W, et al. Treatment of non-specific, functional and somatoform bodily complaints. [Umgang mit Patienten mit nicht-spezifischen, funktionellen und somatoformen Körperbeschwerden.] Dtsch Med Wochenschr. 2014; 139: 602-607. [German]

[17] Kleinstäuber M, Witthöft M, Hiller W. Efficacy of short-term psychotherapy for multiple medically unexplained physical symptoms: a meta-analysis. Clin Psychol Rev. 2011; 31: 146-160.

[18] van Dessel N, den Boeft M, van der Wouden JC, et al. Nonpharmacological interventions for somatoform disorders and medically unexplained physical symptoms (MUPS) in adults. Cochrane Database Syst Rev. 2014; 11: CD011142.

[19] Liu J, Gill NS, Teodorczuk A, et al. The efficacy of cognitive behavioural therapy in somatoform disorders and medically unexplained physical symptoms: a meta-analysis of randomized controlled trials. J Affect Disord. 2019; 245: 98-112.

[20] Hoedeman R, Blankenstein AH, van der Feltz-Cornelis CM, et al. Consultation letters for medically unexplained physical symptoms in primary care. Cochrane Database Syst Rev. 2010; 12: CD006524.

[21] Newby JM, Smith J, Uppal S, et al. Internet-based cognitive behavioral therapy versus psychoeducation control for illness anxiety disorder and somatic symptom disorder: A randomized controlled trial. J Consult Clin Psychol. 2018; 86: 89-98.

[22] Sitnikova K, Leone SS, van Marwijk HW, et al. Effectiveness of a cognitive behavioural intervention for patients with undifferentiated somatoform disorder: results from the CIPRUS cluster ran- 
domized controlled trial in primary care. J Psychosom Res. 2019; 127: 109745.

[23] Burton C, Fink P, Henningsen P, et al., on behalf of the EURONET-SOMA Group. Functional somatic disorders: discussion paper for a new common classification for research and clinical use. BMC Med. 2020; 18: 34-43.

[24] Leutgeb R, Berger S, Szecsenyi J, et al. Patients with somatoform disorders: More frequent attendance and higher utilization in primary out-of-hours care? PLoS ONE 2018; 13: e0202546.

[25] Hausteiner-Wiehle C, Schäfert R, Sattel H, et al. New guidelines on functional and somatoform disorders. [Neue Leitlinien zu funktionellen und somatoformen Störungen]. Psychother Psychosom Med Psychol. 2013; 63: 26-31. [German]

[26] Schaefert R, Hausteiner-Wiehle C, Häuser, W, et al. Non-specific, functional, and somatoform bodily complaints. Dtsch Arztebl Int. 2012; 109: 803-813

[27] Clinical guideline for general practice. Dansk Selskab for Almen Medicin, 2013 (translated into English in 2016). Available from: https://www.eapm.eu.com/wp-content/uploads/2018/06/ clinical-guideline-functional-disorders-dsam-2013.pdf [accessed: August 22, 2020].

[28] Andersen NL, Eplov LF, Andersen JT, et al. Health care use by patients with somatoform disorders: a register-based follow-up study. Psychosomatics 2013; 54: 132-141.

[29] Fischer F, Lewith G, Witt CM, et al. A research roadmap for complementary and alternative medicine - what we need to know by 2020. Forsch Komplementmed. 2014; 21: el-el6.

[30] van der Feltz-Cornelis CM, Elfeddali I, Werneke U, et al. A European research agenda for somatic symptom disorders, bodily distress disorders, and functional disorders: results of an estimate-talk-estimate Delphi expert study. Front Psychiatry 2018; 9: 151 .

[31] Gidding LG, Spigt M, Winkens B, et al. PsyScan e-tool to support diagnosis and management of psychological problems in general practice: a randomised controlled trial. Br J Gen Pract. 2018; 68: e18-e27.

[32] Patel S, Akhtar A, Malins S, et al. The acceptability and usability of digital health interventions for adults with depression, anxiety, and somatoform disorders: Qualitative systematic review and meta-synthesis. J Med Internet Res. 2020; 22: el6228.

[33] Raine R, Haines A, Sensky T, et al. Systematic review of mental health interventions for patients with common somatic symptoms: can research evidence from secondary care be extrapolated to primary care? BMJ 2002; 325: 1082.
[34] van der Feltz-Cornelis CM, Van Os TW, Van Marwijk HW, et al. Effect of psychiatric consultation models in primary care. A systematic review and meta-analysis of randomized clinical trials. J Psychosom Res. 2010; 68: 521-533.

[35] Koelen JA, Houtveen JH, Abbass A, et al. Effectiveness of psychotherapy for severe somatoform disorder: meta-analysis. Br J Psychiatry 2014; 204: 12-19.

[36] Rajna P. Every physician must be (also) a psychiatrist (a little bit). [Minden orvos (legyen) elmegyógyász (is).] Medicina Könyvkiadó, Budapest, 2017. [Hungarian]

[37] Barsky AJ, Ahern DK, Bauer MR, et al. A randomized trial of treatments for high-utilizing somatizing patients. J Gen Intern Med. 2013; 28: 1396-1404.

[38] Kroenke K, Swindle R. Cognitive-behavioral therapy for somatization and symptom syndromes: a critical review of controlled clinical trials. Psychother Psychosom. 2000; 69: 205-215.

[39] Liu J, Gill NS, Teodorczuk A, et al. The efficacy of cognitive behavioural therapy in somatoform disorders and medically unexplained physical symptoms: a meta-analysis of randomized controlled trials. J Affect Disord. 2019; 245: 98-112.

[40] Gidding LG, Spigt M, Winkens B, et al. PsyScan e-tool to support diagnosis and management of psychological problems in general practice: a randomised controlled trial. Br J Gen Pract. 2018; 68: e18-e27.

[41] Kendrick T, Chatwin J, Dowrick C, et al. Randomised controlled trial to determine the clinical effectiveness and cost-effectiveness of selective serotonin reuptake inhibitors plus supportive care, versus supportive care alone, for mild to moderate depression with somatic symptoms in primary care: the THREAD (THREshold for AntiDepressant response) study. Health Technol Assess. 2009; 13: 141-159.

[42] Kleinstäuber M, Witthöft M, Steffanowski A, et al. Pharmacological interventions for somatoform disorders in adults. Cochrane Database Syst Rev. 2014; 11: CD010628.

[43] Mikkelsen MB, Rosholm M. Systematic review and meta-analysis of interventions aimed at enhancing return to work for sick-listed workers with common mental disorders, stress-related disorders, somatoform disorders and personality disorders. Occup Environ Med. 2018; 75: 675-686.

(Rajna Péter dr., Budapest, Hollán E. u. 13-15., 1136 e-mail: rajna@mulltiart.hu)

\title{
Az Orvosi Hetilap 2021; 162: 40. oldalán (1. szám) megjelent OH-Kvízre egy helyes megfejtés érkezett.
}

A beküldő: Dr. Kónya Csaba (Budapest).

A nyertesnek szívböl gratulálunk.

\author{
Nyereményét - egy, az Akadémiai Kiadó webáruházában \\ kedvezményes vásárlásra jogosító kupont - e-mailen küldjük el.
}

A cikk a Creative Commons Attribution 4.0 International License (https://creativecommons.org/licenses/by/4.0/) feltételei szerint publikált Open Access közlemény, melynek szellemében a cikk bármilyen médiumban szabadon felhasználható, megosztható és újraközölhető, feltéve, hogy az eredeti szerző és a közlés helye, illetve a CC License linkje és az esetlegesen végrehajtott módosítások feltüntetésre kerülnek. (SID_1) 